\title{
Rifting processes in NW-Germany and the German North Sea Sector
}

\author{
F. Kockel \\ Eiermarkt 12 B, D-30938 Burgwedel, Germany \\ Manuscript received: September 2000; accepted: January 2002
}

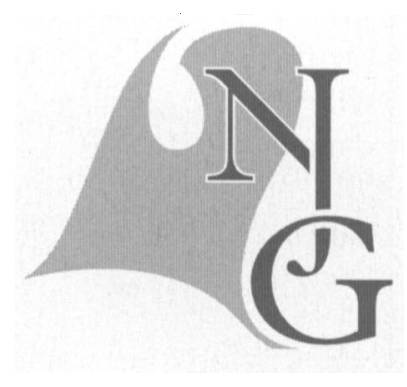

\begin{abstract}
Since the beginning of the development of the North German Basin in Stephanian to Early Rotliegend times, rifting played a major role. Nearly all structures in NW-Germany and the German North Sea - (more than 800) - salt diapirs, grabens, inverted grabens and inversion structures - are genetically related to rifting. Today, the rifting periods are well dated. We find signs of dilatation at all times except from the Late Aptian to the end of the Turonian. To the contrary, the period of the Coniacian and Santonian, lasting only five million years was a time of compression, transpression, crustal shortening and inversion. Rifting activities decreased notably after inversion in Late Cretaceous times. Tertiary movements concentrated on a limited number of major, long existing lineaments. Seismically today NW-Germany and the German North Sea sector is one of the quietest regions in Central Europe.
\end{abstract}

Key words: Rifting, NW Germany, North Sea, Permian, Mesozoic, Tertiary

\section{Introduction}

The area considered here forms part of the mobile epi-Variscan platform on which the Polish-North German and southern North Sea basin developed since the beginning of the Late Permian. This basin with its filling of partly more than $10.000 \mathrm{~m}$ of sediments is by no means the result of a mere subsidence caused by the cooling of an early Permian mantle plume. It represents a complex system of deep rifts and rift basins which had been active in different periods of the Mesozoic (Table 1). The pattern of basement block boundary faults (Fig.1) underlying these rifts originated in Permian and Triassic times and became frequently reactivated later. Modern reflection seismic measurements by the German oil industry permit the exact dating of the fault movements and reveal a highly complex genetic history of the post-
Zechstein structures (salt and inversion structures) straddling and triggered by these basement faults.

\section{Pre-Variscan}

The rifted passive northern margin of the Late Precambrian to Silurian Tornquist Ocean is the oldest well-documented trace of rifting and can be observed in seismic sections off Rügen in the Baltic Sea. The southern margin of Baltica, covered with thin Cambrian sediments, is step-faulted towards the Tornquist Ocean in the SSW. This ocean closed in Early Silurian times and its passive continental margin was thrusted from the south by an internally imbricated accretionary wedge of Ordovician and Early Silurian sediments called the 'Caledonian front' (Pieske \& Neumann, 1991; Schlüter et al., 1997). 


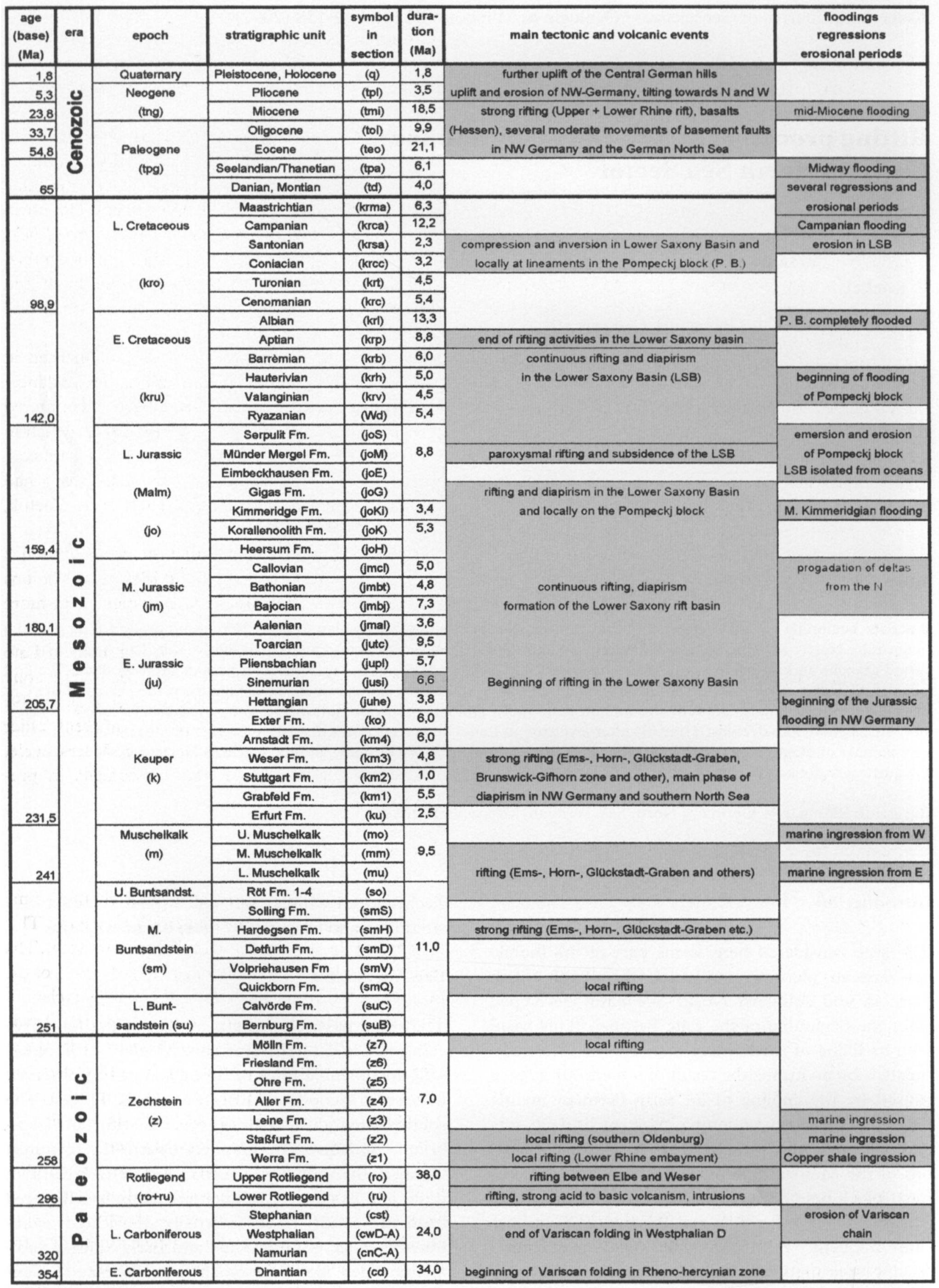

Table 1. Stratigraphic column for NW Germany and major tectonic events. Time scale from Menning (1997) (Carboniferous to Triassic) and Gradstein et al. (1999). 


\section{Variscan}

The central part of the Rheno-Hercynian zone of the Variscan chain was also part of a rift. In Siegenian, Emsian and Eifelian times the Aachen-Midi Thrust near Aachen formed a prominent rift edge south of the Eurasian platform. This was revealed by the balanced reconstruction of a deep seismic DEKORP section (von Winterfeld \&Walter, 1993).

Grabens and half-grabens are cut into the Carboniferous limestone platform of Dinantian age in Central UK and it is possible that they extend towards the east into the North Sea and into Dutch and German waters.

Dinantian rifting has also been assumed for paleogeographic reasons in the Rheno-Hercynian zone of the Variscides to explain the different facies units in the Harz Mountains (Wachendorf et al., 1995). Later compressional overprinting during the Variscan orogeny, however, reshaped these rifts and horst blocks into imbricated thrust zones.

Nevertheless, these early rifting processes had no influence on the genesis of the Mesozoic structures in the North German basin.

\section{Permian}

Block faulting older than Upper Rotliegend is observed in Norwegian and Danish waters north of the Duck's Beak. This rifting is either Stephanian or Early Rotliegend in age. Also onshore, especially in eastern Germany, the Early Rotliegend break-up was very intense. It is, however, extremely difficult to locate the main fault systems, which had formed the feeder channels of the basaltic, andesitic, and acid volcanic extrusions, forming lava, flow piles of up to several thousand metres in thickness. It seems likely that the region of the NNE-trending later Brunswick-Gifhorn fracture zone (Fig. 1) acted as a zone of weakness and was straddled by a chain of calderas. Linking thickness maxima of the volcanics with major fault or rift zones is still not feasible. The rifting phase has been named 'Frankonian' pulse.

The next rifting event took place at the beginning of the Late Rotliegend (Parchim Formation). The rifts formed a fan of grabens in eastern Lower Saxony running more or less N-S to NNE-SSW and NNWSSE (Gast, 1988, 1991). Similar graben structures have also been recognised south of the Flechtingen Block and in SE Brandenburg, but they seem to be a little older, of Early Rotliegend age (Saale pulse) (Helmuth \& Schretzenmayr, 1995). The grabens are filled with volcanic debris and with thick aeolian deposits 'Schneverdingen sands', which are valuable gas reservoir rocks. Rifting was caused by the Altmark IIII pulses. The rift boundary faults are covered by sediments of the Dethlingen Formation (Upper Rotliegend). Some of the faults became reactivated in post-Zechstein times.

There are indications in the German North Sea Sector and in Schleswig-Holstein of rifting continuing into the late Upper Rotliegend times. The halite deposits intercalated in the Dethlingen and Hannover Formations in the Horn Graben and in the Glückstadt Graben are much thicker than on the graben shoulders (Flensburg Z 1 borehole without salt and Schleswig $Z 1$ in the graben with undisturbed and thick Dethlingen and Hannover salts).

The next period of rifting is well documented in the Lower Rhine Graben and in the Netherlands. Half-graben structures there have been encountered containing thick Zechstein 1 (Werra) halite, which in the vicinity is lacking. The graben structures are covered by basal Zechstein 2 sediments and rifting had stopped at the onset of the Stassfurt cycle (Geluk, 1999; Wolf, 1985).

Rifting has also been assumed for the Zechstein 2 (Stassfurt) cycle to explain thickness variations (Ziegler, 1989). This should be investigated in more detail.

A further pulse of rifting can be observed in Late Zechstein times. In the Dutch-German border zone (Best, 1989) and in the Netherlands (Geluk, 1999) the Upper Bröckelschiefer rests on different older Zechstein cycles from the Aller to the Werra cycle, thus indicating strong tectonic movements in preBröckelschiefer times.

\section{Triassic}

The Lower Buntsandstein was a relatively quiet time without indications of rifting in NW-Germany. This changed in the lowermost Middle Buntsandstein. The Quickborn sandstone (Röhling, 1999), the base of the first Middle Buntsandstein sedimentary cycles, is completely eroded in the southern part of the Buntsandstein basin and is only preserved in larger areas in the centre of the basin. In the Ems estuary region the Quickborn sandstone is locally preserved in a graben structure. The graben boundary faults are covered by basal Volpriehausen sandstone.

During the deposition of the Volpriehausen, Detfurth, and Hardegsen formations, rifting can be assumed in the great NNE to NNW-striking rift zones only, the Horn-Ems-Rift, the Glückstadt rift, and the Brunswick-Gifhorn rift (compare Fig. 1). This assumption is based on the anomalous thickness of the Middle Buntsandstein in these rift zones. In the other 


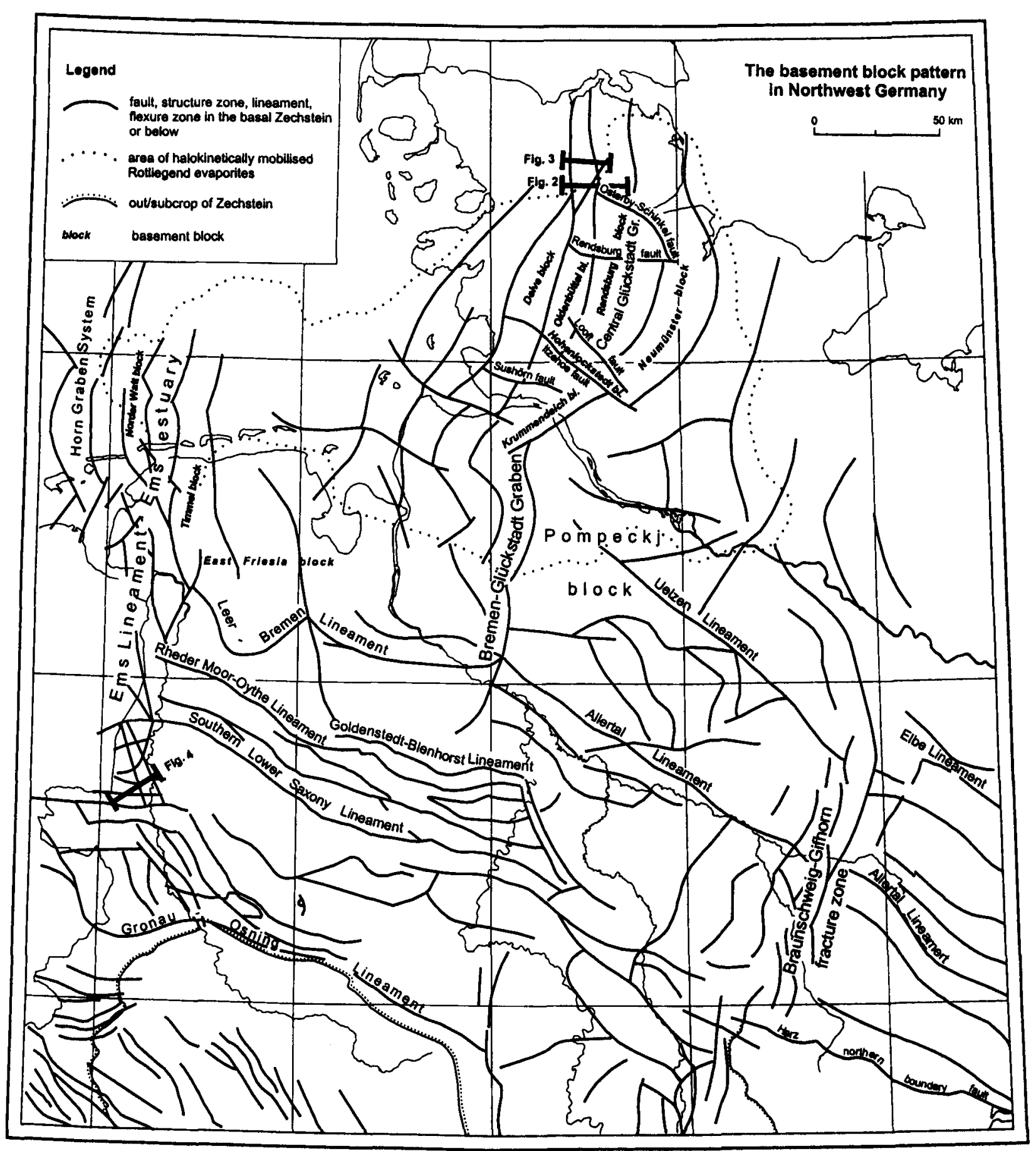

Fig. 1. Basement block pattern in Northwest Germany. Block boundary faults indicate rift zones active in Late Palaeozoic and Mesozoic times (Baldschuhn et al., 1997, unpublished report).

regions of NW-Germany, only slight warping took place with uplift and erosion on the swell regions and subsidence in the troughs, before the next sedimentary cycle started with its basal sandstone (Röhling, 1991).

Nevertheless, a paroxysmal rifting event took place in the uppermost Middle Buntsandstein before the basal Solling unconformity (' $\mathrm{H}$ ' unconformity). In the great, NNE to NNW-trending rift zones mentioned above (see Figs 2 and 3), a complete succes- sion of the Middle Buntsandstein is preserved, whereas sediments on the graben shoulders were quantitatively removed down to the Volpriehausen Formation or even to the Lower Buntsandstein or Zechstein. Also, many generally NW-SE-striking lineaments moved (the Uelzen lineament, the Aller lineament or the 'Südniedersachsen' lineament (Fig. 1). Over these lineaments, synsedimentary elongated grabens, horsts, and halfgrabens originated in the Early Triassic rocks, causing abrupt thickness variations of the 


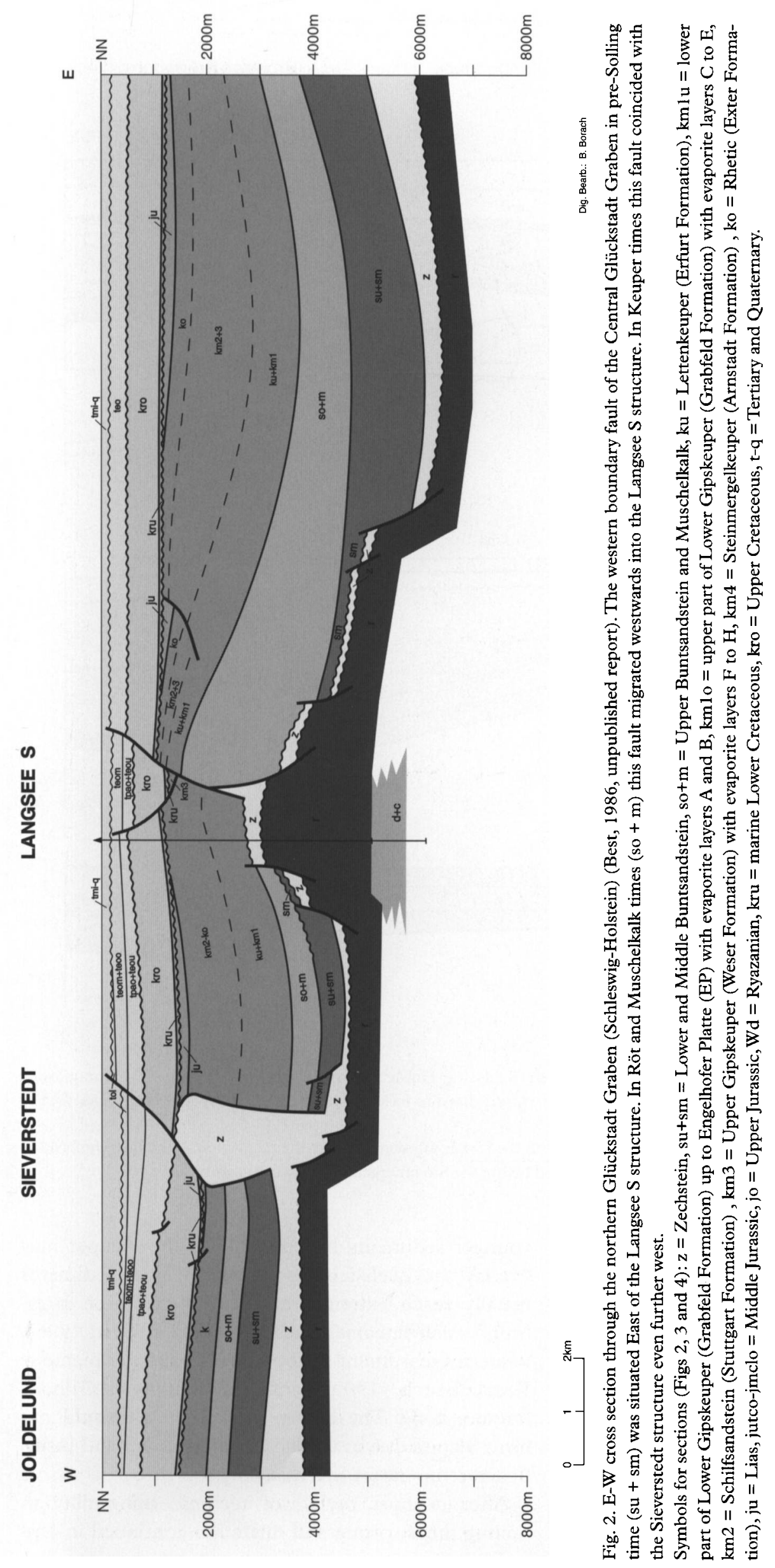

Netherlands Journal of Geosciences / Geologie en Mijnbouw 81(2) 2002 


\section{Northern Glückstadt graben}
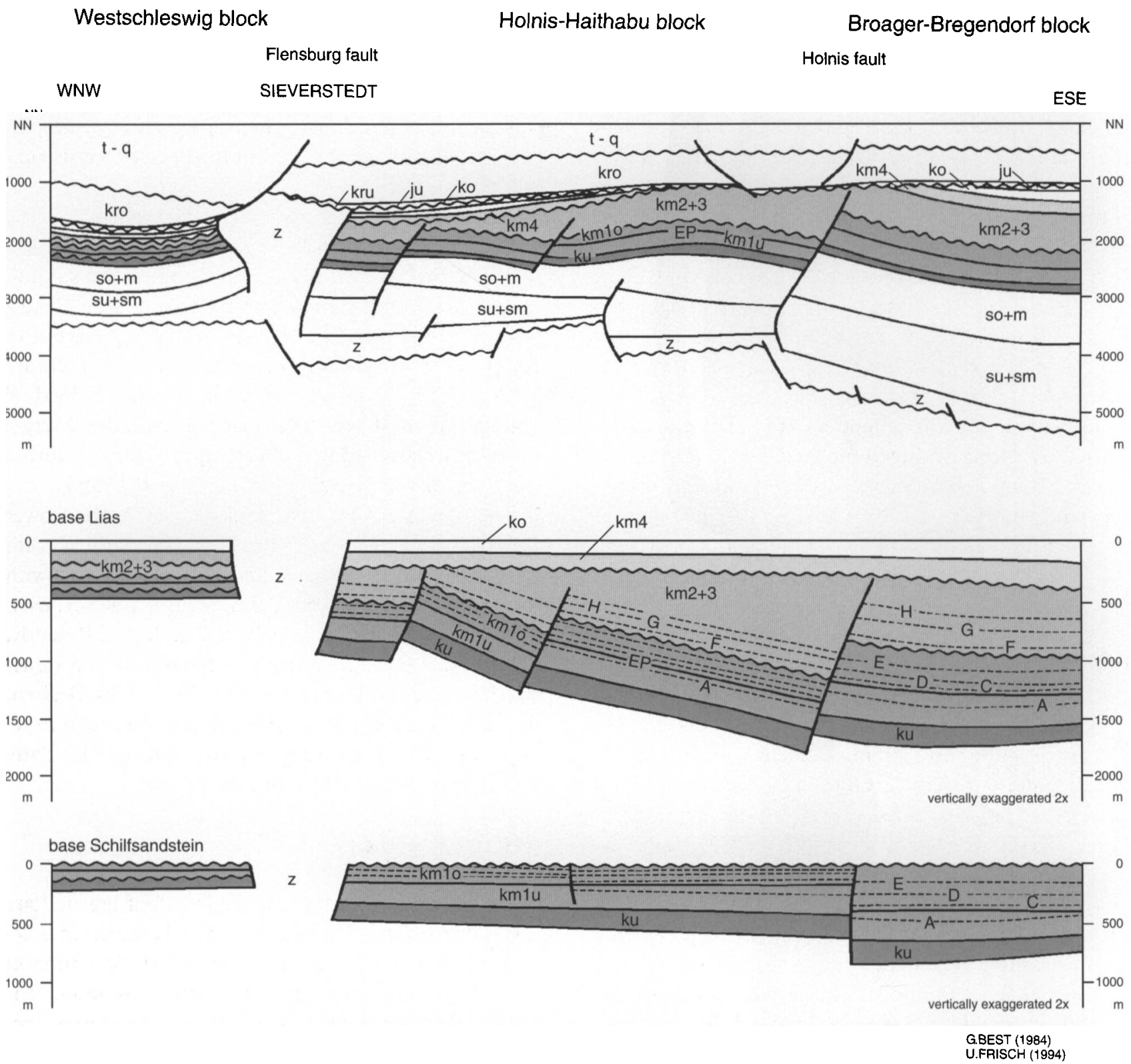

Fig. 3. WNW-ESE-cross section through the northern Glückstadt Graben (Schleswig-Holstein) (from Best, 1986, Frisch, 1994, unpublished reports, Frisch \& Kockel, 1999). Above: present day structure, central: stripped down to base Liassic, bottom: stripped down to base Schilfsandstein. Stripped sections vertically exaggerated 2 times.

The differentiation of the rift margin east of the Flensburg fault starts with the Lower Gipskeuper after the deposition of the Engelhofer Platte (EP) and increases during the Upper Gipskeuper. Taphrogenesis ended before the Steinmergelkeuper unconformity.

pre-Solling sedimentary sequence (Röhling, 1991).

Dilatation during the pre-Solling rifting phase was locally so intense that not only subsidence in grabens occurred but also phenomena, which have been known for the last decade under the term 'rafting' (Best, 1996). Due to extreme extension the Buntsandstein overlying the Zechstein salt was stretched to such an extent, that it burst and broke up into independent 'rafts' with intra-'raft' spaces, in which the Zechstein salt was tectonically denuded from its overburden. In these intra-'raft' spaces Solling and younger sediments like the Röt or the Keuper may overlay the Zechstein salt directly. These sediments usually reach extreme thickness above these intra'rafts': Aller lineament near Morsleben (Best, 1996), western escarpment of the Horn Graben (Thieme \& Rockenbauch, 1999), and the Brunswick-Gifhorn fracture zone. The barren Zechstein salt could not form diapirs due to the lack of overburden and insufficient temperature increase only.

After a short period of tectonic tranquillity in Solling times, rifting and dilatation continued in Up- 
per Buntsandstein and Muschelkalk times. In the major rift zones (Horn Graben - Ems rift, Glückstadt rift - see Figs 2 and 3 - and Brunswick-Gifhorn rift as well as along major NW-SE-running lineaments, a sudden increase in thickness in the vicinity of the faults is observed. In these grabens and half-grabens, the Middle Muschelkalk evaporites are fully developed and sometimes show up to 6 halite layers in contrast to 1 or 2 outside the rifts (Brückner-Röhling, 1999).

The second major rifting event during the Early Cimmerian tectonic phase took place during the Middle Keuper (Frisch \& Kockel, 1999). The Lower Gipskeuper (Grabfeld Formation) reaches thicknesses of up to $5000 \mathrm{~m}$ in the graben zones and only 200 $-300 \mathrm{~m}$ on the rift shoulders. This is only partly caused by rifting and tectonic subsidence. Strong dilatation caused the break-up of the Triassic overburden and Zechstein and Rotliegend salt to migrate into the faults and gaps. Salt diapirs originated, straddling the border faults in the basement blocks. The filling of the 'secondary rim synclines' with Gipskeuper sediments compensated the mass deficit caused by the migration of the Permian salt into the diapir. The thick sedimentary piles thus result partly from halokinetic and partly from ortho-tectonic processes. After a short period of an extreme lowstand, when the fluviatile Schilfsandstein (Stuttgart Formation) was deposited, rifting continued during Upper Gipskeuper times (Weser Formation), but stopped in nearly all the grabens before the deposition of the Steinmergelkeuper (Arnstadt Formation). The base of the Steinmergelkeuper (and not that of the Rhetic) thus forms the Early Cimmerian main unconformity. The mechanism and timing of the rifting processes are demonstrated by cross-sections stripped down to base Liassic and base Schilfsandstein (Figs 3 and 4).

During the Triassic rifting in the three main NNE to NNW-striking rift-zones (Fig. 1), the Horn Graben - Ems rift in the western part, the Glückstadt rift in the central part, and the Brunswick-Gifhorn rift zone in the eastern part of Northwest Germany occurred. But also other lineaments, crossing NW Germany in a general NW-SE direction, the so-called 'Hercynian' direction, were active to a minor extent.

\section{Jurassic}

This structural pattern changed with the beginning of the Jurassic. Up to now it was generally believed that the development of the Lower Saxony 'basin', a WNW-ESE-trending sub-basin of the North German Basin, first started in Late Jurassic times. This is definitively wrong. In the Lower Saxony rift basin, there are many indications for a strong rifting in the Liassic as well as in the Middle Jurassic. Maps showing all the faults active during the Liassic and Middle Jurassic (Baldschuhn et al., 2001) clearly demonstrate the strong influence of rift tectonics on sedimentation in this period in the Lower Saxony basin, especially in the zone, which we call the 'Südniedersachsen' Lineament.

The rifting in the Lower Saxony graben and the Brunswick-Gifhorn fracture zone, which was formerly called the 'Gifhorn trough', indeed reached its peak during the Upper Jurassic, precisely in the Portlandian 'Münder Mergel'. Late Jurassic rifting started in pre-Middle Kimmeridgian times (Gramann et al., 1997). The most intense subsidence of the individual grabens in the basin took place in Münder Mergel times but slowed down considerably already during the Purbeckian 'Serpulit' (Gramann et al., 1996).

The Late Jurassic horsts and grabens in the Lower Saxony basin are by no means always identical with those active in the Middle and Early Jurassic or with those active in the Early Cretaceous. Moreover, each graben boundary fault behaved rather differently. Some faults became inactive at the end of the Jurassic, like the boundary faults of the inner Hils-Graben, the Holzen-Greene fault, some faults continued moving even with increasing velocity during the Early Cretaceous until the Middle Aptian.

\section{Early Cretaceous}

An example of tectonic continuity of rifting in Late Jurassic and Early Cretaceous times is shown in a N$\mathrm{S}$ cross section through the Emsland (Baldschuhn et al., 1991). This proves that the 'Late Cimmerian unconformity' is not a result of a 'Late Cimmerian tectonic revolution' but only a consequence of a global fall in sea-level at the end of the Jurassic followed by a continuous sea-level rise in the Early Cretaceous. The rifting in the Lower Saxony basin continued during the Early Cretaceous and was not influenced by the sea-level changes.

Small grabens and half-grabens active in Early Cretaceous times are the so-called 'Kolke' in the Salzgitter area, in which the conglomeratic iron ores of Salzgitter type were trapped to form minable ore deposits.

A map containing all the faults active in Early Cretaceous times (Baldschuhn et al., 2001) shows that the former large rifts like the Horn-Ems rift and the Glückstadt rift, both very active during the Triassic, remained inactive during the entire Jurassic and Early Cretaceous.

Rifting activity throughout NW-Germany and the 

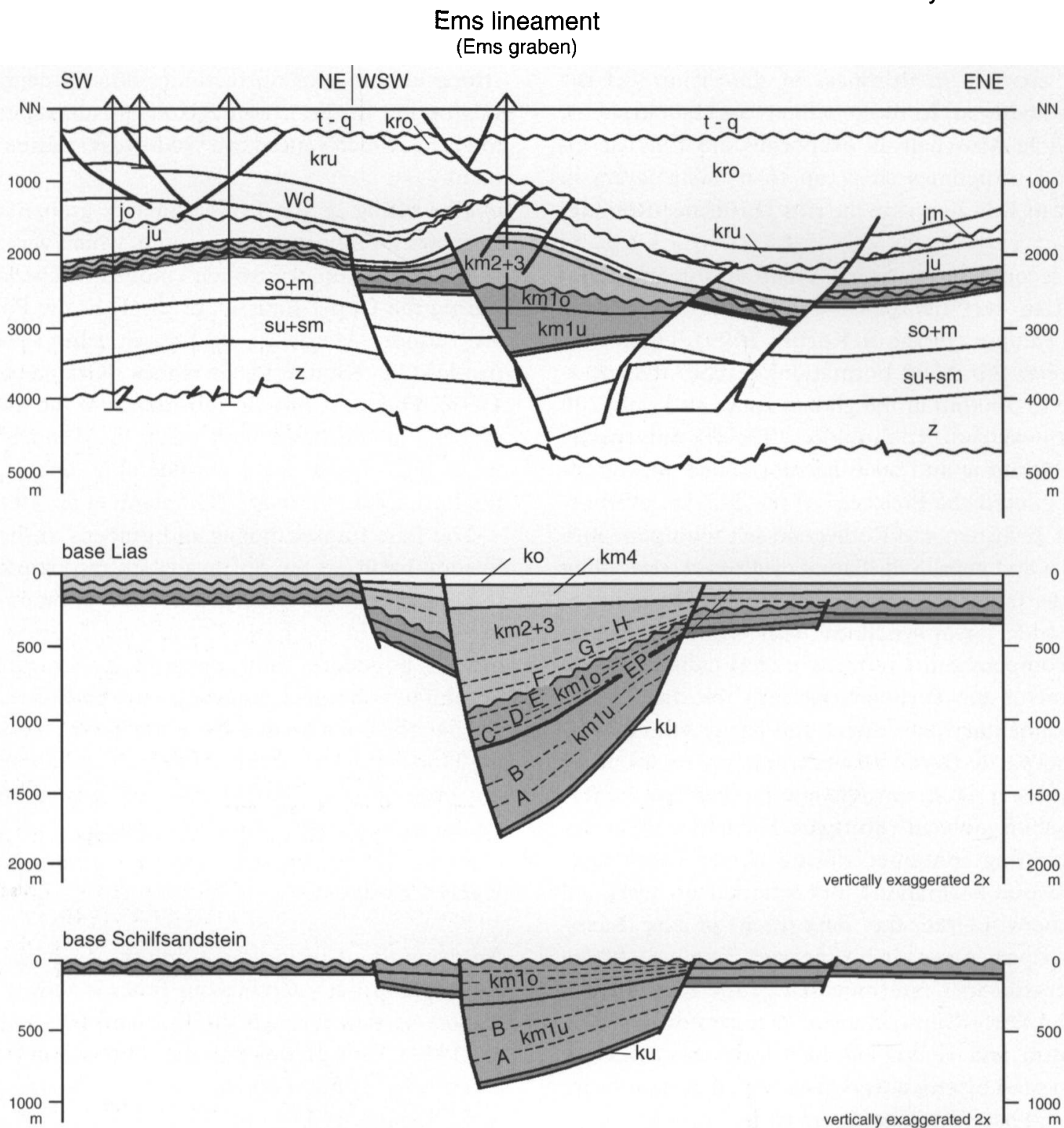

R.BALDSCHUHN (1996)

U.FRISCH (1994)

Fig. 4. SW-NE section through the middle part of the Ems Graben (Frisch, 1994, Baldschuhn, 1996, unpublished reports, Frisch \& Kockel, 1999). Above: present-day structure, central: stripped down to base Liassic, bottom: stripped down to base Schilfsandstein. Stripped sections vertically exaggerated 2 times. Symbols see Fig. 2.

Rifting in the Ems Graben started in Lower Gipskeuper times $(\mathrm{kml} \mathrm{u}+\mathrm{o})$ and continued during Upper Gipskeuper times. The Steinmergelkeuper and the Rhetic are, to a lesser extent, still affected by rifting. The Triassic graben feature in Late Cretaceous times was affected by inversion of the Rühle-Wettrup block.

German North Sea ceased in Middle Aptian times. Fault activities in latest Aptian, Albian, Cenomanian, or Turonian times are very rare. These formations have to be regarded as post-rift sediments.

\section{Late Cretaceous}

During the Coniacian and Santonian many, but not all of the Jurassic to Early Cretaceous grabens be- came inverted (Baldschuhn et al., 1991). Rifting and inversion influenced each other. In areas without rifting there also was no inversion.

\section{Tertiary}

The Tertiary was the main rifting time for the Upper Rhine Graben and Lower Rhine and Roer Valley rift systems. However, in NW Germany and the German 
North Sea sector there is not much tectonic activity during the Tertiary. Long and deep rifts can be found neither at the base of the Tertiary nor in the isopach maps of the different Tertiary stages. There are some active faults, many of them in the crest of covered salt structures indicating either halokinetic movements of the salt or reactivation of basement faults, which are straddled by the salt structures. Many of these faults, especially in the North Sea, were active in post-Middle Miocene times, like the Görtel fault, which limits the Island of Helgoland to the SW (Binot \& Röhling, 1988). Also, the boundary faults of the Horn Graben and its extensions towards the Ems rift became reactivated in Late Miocene times. The Triassic Glückstadt graben system on the other hand shows indications of Tertiary inversion and uplift, as a deep marginal trough ('Hamburger Loch') formed over its former eastern shoulder (Baldschuhn et al., 1996: section 112). But there is no rift comparable with the Upper Rhine Graben or the Lower Rhine and Roer Valley grabens. The eastern limb of the 'Y'-shaped rift structure, which is supposed to branch off from the Upper Rhine Graben at Frankfurt, incorporating the Tertiary depocentres in Hessen and the Leinetal graben, and believed to continue into the Brunswick-Gifhorn fracture zone, did not exist in Tertiary times. What we see, are old Triassic or Jurassic graben systems or fracture zones, almost or entirely inactive since the beginning of the Tertiary.

Many of the reverse and thrust faults bordering the Late Cretaceous inversion structures experienced reverse reactivation during the Tertiary. They act as normal faults in opposite direction to the compressional stress during inversion. These movements thus can be regarded as relaxation of the Late Cretaceous compression in the basement and in the Mesozoic overburden (Forsbach, unpubl.)

The basal mid-Miocene reflector (Reinbek reflector) is the youngest datable reflector which can be followed throughout the German North Sea sector and the northern part of NW Germany. There is sufficient seismic evidence from the Southern North Sea, that the faults on the crests of the Keuper aged salt diapirs, which disturb this basal mid-Miocene reflector and which were triggered by basement block fault movements, are generally covered by younger, Late Miocene, Pliocene, or even Early Pleistocene deposits. The salt structures, which clearly show up as positive elongated fractured anticlines in the basal Mid-Miocene isocontour map in most cases cannot be traced in younger levels, like the isocontour map of the base Quaternary. An exception is the anticline of Helgoland Island, which is rising even today. During the Quaternary and until today, NW Germany and the German North Sea sector seismically are the quietest regions in Central Europe.

\section{Acknowledgements}

G. Dresen (Potsdam) and R. Vinken (Hannover) are thanked for constructive reviews of the manuscript.

\section{References}

Baldschuhn, R., Best, G. \& Kockel, F, 1991. Inversion tectonics in the Northwest German Basin. In: Spencer, A. M. (ed.): Generation, accumulation and production of Europe's hydrocarbons. Special publication of the European Association of Petroleum Geoscientists 1. Oxford University Press (Oxford): 149-159.

Baldschuhn, R., Frisch, U. \& Kockel, F., 1996. Geotektonischer Atlas von NW-Deutschland 1:300 000, Teil 1-17. Bundesanstalt für Geowissenschaften und Rohstoffe (Hannover): 14 Strukturkarten, je 4 Blätter, 2 abgedeckte Karten, je vier Blätter, 7 Profiltafeln.

Baldschuhn, R., Binot, F., Fleig, S. \& Kockel, F. (eds), 2001. Geotektonischer Atlas von NW-Deutschland und des deutschen Nordsee-Sektors. - Strukturen, Strukturentwicklung, Paläogeographie. Geologisches Jahrbuch A 153: 1-40 (in press).

Best, G., 1989. Die Grenze Zechstein-Buntsandstein in Nordwestdeutschland nach Bohrlochmessungen. Zeitschrift der Deutschen Geologischen Gesellschaft 140: 73-85.

Best, G., 1996. Floßtektonik in Norddeutschland: Erste Ergebnisse reflexionsseismischer Untersuchungen an der Salzstruktur 'Oberes Allertal'. Zeitschrift der Deutschen Geologischen Gesellschaft 147 (4): 455-464.

Binot, F. \& Röhling, H.-G., 1988. Lithostratigraphie und natürliche Gamma-Strahlung des Mittleren Buntsandsteins von Helgoland. Ein Vergleich mit der Nordseebohrung J/18-1. Zeitschrift der Deutschen Geologischen Gesellschaft 139: 33-49.

Brückner-Röhling, S., 2000. Chemocyclicity in the Middle Muschelkalk of Northern Germany. Zentralblatt für Geologie und Paläontologie, Teil I, 1998: 941-951.

Frisch, U. \& Kockel, F., 1999. Early Cimmerian movements in Northwest Germany. Zentralblatt für Geologie und Paläontologie, Teil I, 1998: 571-600.

Gast, R., 1988. Rifting im Rotliegenden Niedersachsens. Die Geowissenschaften 6: 115-122.

Gast, R., 1991. The perennial Rotliegend Saline Lake in NW-Germany. Geologisches Jahrbuch A 1 19: 25-59.

Geluk, M.C., 1999. Late Permian (Zechstein) rifting in the Netherlands: models and implications for petroleum geology. Petroleum Geoscience 5: 189-199.

Gradstein, F.M., Agterberg, F.P., Ogg, J.G., Hardenbol., J \& Backstrom, S., 1999. On the Cretaceous time scale. Neues Jahrbuch für Geologie und Paläontologie, Abhandlungen 212:3-14.

Gramann, F., Heunisch, C., Klassen H., Kockel, F., Dulce G., Harms, F.J., Katschorek, T., Mönning, E., Schudack, M., Schudack, U., Thies, D., Weiss, M. \& Hinze, C., 1997. Das Niedersächsische Oberjurabecken - Ergebnis interdisziplinärer Zusammenarbeit. Zeitschrift der Deutschen Geologischen Gesellschaft 148: 165-236.

Gramann, F., Kockel, F. \& Röhling, H.-G., 1996. Leinebergland zwischen Banteln und Stadtoldenfdorf, Exkursion C. In: Feldmann, L. \& Quade, H.(eds): Der Untergrund der Norddeutschen Tiefebene. Exkursionsführer und Veröffentlichungen der Gesellschaft für Geowissenschaften 197: 149-179.

Helmuth, H.J. \& Schretzenmayr, S., 1995. Zur raum-zeitlichen 
Genese der Gräben. In: Plein, E. (ed.): Stratigraphie von Deutschland I, Norddeutsches Rotliegendbecken. RotliegendMonographie Teil II. Courier Forschungsinstitut Senckenberg 183: 169-174.

Menning, M., 1997. Geologische Zeitskala der Mark Brandenburg. 1 Bl. Geoforschungs-zentrum (Potsdam).

Pieske, J. \& Neumann, E., 1993. Tektonische Gliederung des prävariszischen Untergrundes in der südlichen Ostsee. Geologisches Jahrbuch A 131: 361-388.

Röhling, H.-G., 1991. Lithostratigraphie und Paläogeographie des Unteren und Mittleren Buntsandsteins im Nordwestdeutschen Becken. Eine Analyse der Schichtenfolge mit Hilfe geophysikalischer Bohrlochmessungen (Gamma-Ray und Sonic Log). Unpublished Dissertation University of Heidelberg: $336 \mathrm{pp}$.

Röhling, H.-G., 1999. The Quickborn sandstone - a new lithostratigraphic unit in the lowermost Middle Buntsandstein (Skythian). Zentralblatt für Geologie und Paläontologie, Teil I, 1998: 797-812.

Schlüter, H.-U., Best, G., Jürgens, U. \& Binot, F., 1997. Interpreta- tion reflexionsseismischer Profile zwischen baltischer Kontinentalplatte und kaledonischem Becken. - Erste Ergebnisse. Zeitschrift der Deutschen Geologischen Gesellschaft 148: 1-32.

Thieme, B. \& Rockenbauch, K., 1999. Floßtektonik ('raft tectonics') in der Trias der südlichen Nordsee. DGMK Tagungsbericht 990-1: 65-79.

Von Winterfeld, C. \& Walter, R., 1993. Die variszische Deformationsfront des nordwestlichen Rheinischen Schiefergebirges - ein bilanziertes geologisches Tiefenprofil über die Nordeifel. Neues Jahrbuch für Geologie und Paläontologie, Monatshefte, 1993: 305-320.

Wachendorf, H., Buchholz, P. \& Zellmer, H., 1995. Fakten zum Harz-Paläozoikum. Nova Acta Leopoldina 71: 119-150.

Wolf, R., 1985. Tiefentektonik des linksniederrheinischen Steinkohlengebirges - Beiträge zur Tiefentektonik westdeutscher Steinkohlenlagerstätten. Geologisches Landesamt NordrheinWestfalen (Krefeld): 105-167.

Ziegler, M. A., 1989. North German Zechstein facies pattern in relation to their substrate. Geologische Rundschau 78: 105-127. 